\author{
JURNAL LAMPUHYANG \\ LEMBAGA PENJAMINAN MUTU \\ STKIP AGAMA HINDU AMLAPURA
}

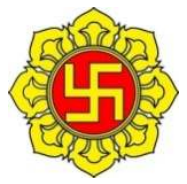

Volume 13 Nomor 1 Januari 2022

p-ISSN: 2087-0760; e-ISSN: 2745-5661

https://e-journal.stkip-amlapura.ac.id

\title{
Strategi Komunikasi dalam Sosialisasi Upaya Penanggulangan Covid-19 \\ melalui Pupuh
}

\author{
Ni Kadek Juliantari' ${ }^{1}$, I Nyoman Subadra ${ }^{2}$ \\ 1,2STKIP Agama Hindu Amlapura \\ 1'kadekjuliantari755@yahoo.co.id
}

\begin{abstract}
Abstrak: Artikel ini bertujuan untuk mendeskripsikan strategi komunikasi dalam sosialisasi untuk menanggulangi penyebaran Covid-19 di masyarakat. Artikel ini ditulis dengan menggunakan pendekatan kualitatif jenis fenomenologi. Pendekatan kualitatif jenis fenomenologi adalah salah satu jenis pendekatan dalam penelitian atau kajian kualitatif yang menekankan pada gejala/fenomena kasuistik yang terjadi secara alamiah di masyarakat. Metode pengumpulan data yang digunakan dalam penelitian ini adalah studi kepustakaan, observasi, dan wawancara mendalam. Analisis data dilakukan pula secara kualitatif dengan teknik induksi dan argumentasi. Hasil penelitian ini menunjukkan bahwa literasi masyarakat terkait dengan Covid-19 masih mengalami bias kognitif sehingga perlu penyadaran masyarakat melalui berbagai strategi. Salah satunya adalah melalui penggunaan pupuh sebagai salah satu strategi penyosialisasian upaya penanggulangan Covid-19. Pupuh yang dominan digunakan adalah pupuh Ginada, Ginanti, dan Sinom. Melalui penggunaan pupuh tersebut, pesan terkait upaya penanggulangan Covid-19 dikemas dengan keratif dan dengan bahasa yang persuasif.
\end{abstract}

Kata kunci: strategi komunikasi, sosialisasi, Covid-19, pupuh

\begin{abstract}
This article aims to describe communication strategies in socialization to tackle the spread of Covid-19 in the community. This article is written using a phenomenological type approach. The qualitative approach of phenomenology is one of the approaches in qualitative research on the types of casuistic symptoms that occur naturally in society. Data collection methods used in this research are literature study, observation, and in-depth interviews. Data analysis was carried out qualitatively with induction and argumentation techniques. The results of this study indicate that public literacy related to Covid-19 is still experiencing cognitive bias, so public awareness is needed through various strategies. One of them is through the use of pupuh as one of the socialization strategies for the Covid-19 response. The dominant pupuh used are Ginada, Ginanti, and Sinom pupuh. Through the use
\end{abstract}


of this pupuh, messages related to efforts to overcome Covid-19 are packaged creatively and in persuasive language.

\section{Keywords: communication strategy, socialization, Covid-19, pupuh}

\section{PENDAHULUAN}

Wabah Covid-19 semakin meluas. Pandemi itu berdampak secara signifikan bagi kehidupan masyarakat Indonesia. Berbagai informasi terkait dengan Covid19 ini pun bermunculan dan menjadi ternding topik setiap hari pada beragam media massa ataupun media sosial. Namun, dari sejumlah informasi yang ada tidak sedikit yang justru menimbulkan kesimpangsiuran di tengah-tengah masyarakat. Kesimpangsiuran informasi terkait dengan Covid-19 juga terkadang membuat masyarakat ragu dan resah antara percaya dan tidak percaya terhadap adanya virus Covid-19 ini. Di satu sisi, dengan berbagai bukti yang ditampilkan di media massa ataupun media sosial ada rasa percaya terhadap keberadaan Covid-19 itu. Namun, di sisi lain, berita-berita di media lainnya dan pernyataan-pernyataan para ahli terkadang juga menguatkan rasa keraguan terhadap keberadaan Covid-19 tersebut.

Bergulirnya berbagai informasi terkait dengan Covid-19, tidak jarang membuat masyarakat resah. Dari banyaknya berita tentang Covid-19 yang beredar di masyarakat sebagian di antaranya merupakan berita bohong (hoaks) yang dengan yang terlalu dibumbui oleh pihak-pihak tidak bertanggung jawab sehingga mengakibatkan kekacauan di masyarakat (Kominfo, 2020). Mulai dari foto-foto mayat yang berserakan di jalan raya dan sangat mengerikan, hingga narasi-narasi yang berbau menyesatkan pemikiran masyarakat (Khoirul, 2020).

Tidak jarang pula informasiinformasi yang beredar terkait dengan Covid-19 di masyarakat ditanggapi dengan bias oleh masyarakat. Bias yang terjadi di masyarakat terkait dengan Covid-19 tersebut disebut dengan bias kognitif akibat kesalahan atau kesesatan proses berpikir yang terjadi secara sistematis (Buana, 2020). Artinya, bias kognitif itu bisa terjadi karena persepsi seseorang yang berbeda dalam memahami sesuatu. Agar bias kognitif ini tidak terjadi tentu literasi masyarakat terkait dengan 
pandemi Covid-19 ini harus dioptimalkan dengan berbagai cara. Salah satunya adalah menerapkan strategi sosialisasi yang tepat.

Menurut Mulyadi dan Risminawati (2012), strategi merupakan segala usaha atau upaya operasional yang dilakukan untuk pencapaian tujuan secara optimal. Hal itu ditegaskan pula oleh Sanjaya (2009) dan Anitah (2008), yang menyatakan bahwa strategi merupakan prosedur operasional dalam bertindak untuk mencapai sasaran yang telah ditentukan dengan mengerahkan segala sumber daya dan upaya secara efektif dan efesien. Berdasarkan beberapa pendapat di atas dapat disimpulkan bahwa strategi merupakan segala usaha ataupun upaya yang dilakukan secara prosedural dan sistematis untuk mencapai tujuan yang telah dutetapkan secara efektif dan efesien melalui dukungan berbagai sumber daya yang dimiliki.

Berkenaan dengan hal tersebut, muncul ketertarikan untuk menyusun artikel ilmiah terkait dengan strategi komunikasi dalam penyosialisasian penanggulangan Covid-19 melalui pupuh . Artikel ini bertujuan untuk mendeskripsikan strategi komunikasi dalam penyosialisasian upaya penanggulangan Covid-19 melalui pupuh . Nantinya, artikel ini dapat dimanfaatkan untuk menambah literasi masyarakat terkait dengan pandemi Covid-19 dan sebagai rujukan dalam melakukan sosialisasi penanggulangan Covid-19 dengan berbagai strategi yang relevan dan inovatif.

Kajian semacam ini telah banyak dilakukan oleh penulis lainnya, tetapi dalam fokus yang berbeda-beda. Buana (2020) menulis artikel tentang analisis perilaku masyarakat Indonesia dalam menghadapi pandemi Virus Corona (Covid-19) dan kiat menjaga kesejahteraan jiwa. Dalam artikel tersebut diuraikan bahwa masih banyak masyarakat Indonesia yang tidak mematuhi imbauan dari pemerintah untuk menanggulangi pandemi virus corona ini. Penyebabnya adalah adanya kesalahan konsep berpikir yang dalam psikologi disebut bias kognitif. Rahmatullah (2020) menulis artikel terkait jaminan hak kesehatan pekerja work from office selama masa PSBB Covid-19. Dalam artikel ini diulas bahwa setiap pekerja pada dasarnya para pekerja memiliki Hak Asasi Manusia (HAM) untuk 
mendapatkan jaminan kesehatan dan keselamatan kerja yang wajib diperhatikan oleh pihak tempatnya bekerja. Bagi sebuah perusahaan atau kantor, para pekerja adalah komponen utama untuk menggerakkan roda keberlangsungan perusahaan dan merupakan salah satu aset perusahaan bidang sumber daya manusia (SDM) yang sangat vital bagi keberlangsungan perusahaan tersebut. Oleh karena itu, sudah sepantasnya menjadi kewajiban perusahaan untuk melakukan segala upaya preventif ataupun kuratif dalam menjamin kesehatan dan keselamatan kerja para pekerjanya tersebut.

Berdasarkan kajian relevan tersebut dapat dilihat bahwa kajian yang dilakukan ini menampilkan sesuatu yang baru, yakni mengkaji strategi komunikasi yang di dalamnya terimplisit pula pola komunikasi dalam penyosialisasian terkait upaya penanggulangan Covid-19 melalui penggunaan pupuh. Selain itu, kajian yang dilakukan ini juga difokuskan pada wilayah Karangasem, Bali dengan menggunakan desain kualitatif jenis fenomenologi. Artinya, terfokus pada fenomena atau gejala kasuistik yang terjadi di Karangasem, Bali. Dengan adanya aspek kebaruan dalam kajian ini yang belum pernah dilirik oleh penulis lainnya menjadikan kajian ini sangat penting dilakukan untuk mengurai permasalahan sosial yang terjadi di masyarakat akibat adanya pandemi Covid-19 dan sekaligus memberikan solusi atas permasalahan tersebut.

\section{TINJAUAN PUSTAKA}

Pupuh merupakan tembang khas Bali yang terikat oleh jumlah baris dan persajakan/rima akhir tiap baris, dan ditulis dengan menggunakan Bahasa Bali. Jenis-jenis pupuh yang ada di antaranya adalah Pupuh Pucung, Pupuh Ginada, Pupuh Ginanti, Pupuh Semarandana, Pupuh Pangkur, dan Pupuh Sinom.

Strategi komunikasi berkaitan dengan cara-cara yang dilakukan dalam tindak komunikasi untuk mencapai efektivitas dan efesiensi komunikasi (Juliantari, 2019). Komunikasi sendiri diartikan sebagai interaksi yang dilakukan untuk menyampaikan kesan dari pembicara kepada pendengar atau sebaliknya.

Menurut Mulyadi dan Risminawati (2012), strategi merupakan segala usaha atau upaya operasional 
yang dilakukan untuk pencapaian tujuan secara optimal. Hal itu ditegaskan pula oleh Sanjaya (2009) dan Anitah (2008), yang menyatakan bahwa strategi merupakan prosedur operasional dalam bertindak untuk mencapai sasaran yang telah ditentukan dengan mengerahkan segala sumber daya dan upaya secara efektif dan efesien. Berdasarkan beberapa pendapat di atas dapat disimpulkan bahwa strategi merupakan segala usaha ataupun upaya yang dilakukan secara prosedural dan sistematis untuk mencapai tujuan yang telah dutetapkan secara efektif dan efesien melalui dukungan berbagai sumber daya yang dimiliki.

\section{METODE PENELITIAN}

Pendekatan yang digunakan dalam penulisan artikel ini pendekatan kualitatif yang berorientasi pada pemaparan bersifat naratif verbal. Secara spesifik, jenis pendekatan kualitatif yang digunakan adalah fenomenologi. Pendekatan kualitatif jenis fenomenologi adalah salah satu jenis pendekatan dalam penelitian atau kajian kualitatif yang menekankan pada gejala kasuistik yang terjadi secara alamiah di masyarakat, yang dalam kajian ini berkaitan dengan literasi masyarakat terhadap adanya Covid-19 dan strategi komunikasi dalam sosialisasi yang ditempuh untuk menanggulangi penyebaran Covid-19. Data dalam artikel ini dikumpulkan dengan berbagai cara untuk memperoleh keabsahan data dalam kajian kualitatif, yakni melalui studi kepustakaan, observasi, dan wawancara mendalam. Studi kepustakaan merupakan cara pengumpulan data penelitian melalui mengkaji berbagai literatur atau pustaka, seperti jurnal ilmiah, buku, artikel dalam media massa, ataupun data statistika yang tersaji dalam berbagai sumber kepustakaan digital ataupun tidak. Observasi dilakukan melalui pengamatan di lingkungan sekitar dan masyarakat terkait dengan literasi masyarakat dan strategi sosialisasi pencegahan Covid-19. Sementara itu, wawancara mendalam dilakukan melalui bertanya kepada pihakpihak yang berkompeten terkait dengan kajian yang dilakukan.

Metode kepustakaan, observasi, dan wawancara tersebut digunakan untuk mengumpulkan data terkait permasalahan penelitian ini, yakni strategi komunikasi dalam penyosialisasian yang dilakukan untuk pencegahan atau penanggulangan Covid-19 melalui pupuh. Data yang 
diperoleh selanjutnya dianalisis secara kualitatif dengan teknik induksi dan argumentasi sebagai dasar melakukan verifikasi dan penarikan simpulan sebagaimana yang dikemukakan dalam model kualitatif Miles \& Huberman, yang terdiri atas pengumpulan data, reduksi data, pengolahan data, serta verifikasi dan penarikan simpulan yang dilangsungkan secara kontinu atau berkesinambungan.

\section{HASIL DAN PEMBAHASAN}

Hasil dan pembahasan pada bagian ini difokuskan pada bentuk Pupuh yang digunakan sebagai media mengomunikasikan atau menyampaikan pesan terkait upaya penganggunalan Covid-19 dan pesan persuasif yang terkandung dalam pupuh tersebut.

Pupuh merupakan tembang khas Bali yang terikat oleh jumlah baris dan persajakan/rima akhir tiap baris, dan ditulis dengan menggunakan Bahasa Bali. Beberapa tembang khas Bali (pupuh) yang diciptakan semasa pandemi Covid-19 yang isinya berkaitan erat dengan penyosialisasian Covid-19 kepada masyarakat.

Bentuk pupuh yang digunakan sebagai strategi mengomunikasikan pesan terkait upaya penanggulangan Covid-19 secara umum terdapat beberapa pupuh, yakni pupuh Ginada, pupuh Ginanti, dan pupuh Sinom. Pupuh Ginada terdiri atas 7 baris dengan pada lingsa sebagai berikut: 8a-8i-8a-8u-8a-4i-8a. Pupuh Ginanti terdiri atas 6 baris dengan pada lingsa sebagai berikut: $8 u-8 i-8 a-8 i-8 a-8 i$. Pupuh Sinom terdiri atas 10 baris dengan pada lingsa sebagai berikut: $8 \mathrm{a}-8 \mathrm{i}-8 \mathrm{a}-8 \mathrm{i}-7 \mathrm{i}-8 \mathrm{u}-$ 8a-8i-4u-8i. Berikut petikan pupuh tersebut beserta terjemahannya.

1) Pupuh Ginada

Data 1

Gumine ketiben baya (8a)

Guru wisesa anutin (8i)

Laksana ngeret indria (8a)

Pang state doh ring grubug (8u)

Amati lelungan (6a)

Lan sutrepti (4i)

Mangda rahayu kepanggih (8i)

Artinya:

Dunia dilanda bencana

Ikuti pemerintah

Perilaku kendalikan indera

Agar senantiasa terhindar wabah Jangan bepergian

Laksanakan dengan patuh, tertib dan damai

Agar anugerah kesehatan dan keselamatan kita dapatkan

Pada baris ke-5 (Amati lelungan) dan baris ke-7 (Mangda rahayu kepanggih) terdapat pelanggaran kaidah pada lingsa yang seharusnya 
adalah baris ke-5 $8 a$ dan baris ke-7 juga $8 a$.

\section{Data 2}

Kenkenang baan medaya (8a)

Metegul ne tanpa tali (8i)

Mekenta joh payu jumah (8a)

Ngalih gae uber virus (8u)

Jagate jani corona (8a)

Mogi gelis (4i)

metilar virus corona (8a)

Artinya:

Bagaimana caranya menyikapi

Kini kehidupan terasa amat terbatas seperti diikat tapi tanpa tali

Tinggal di rumah perut menjadi kelaparan

Kalau bekerja takut terkena virus corona

Dunia sekarang sedang dilanda bencana wabah virus corona

Semoga cepat

virus corona musnah

Pupuh Ginada di atas sudah sesuai dengan aturan pada lingsa tiap baris, yakni $8 a-8 i-8 a-8 u-8 a-4 i-8 a$.

\section{Data 3}

Sedih rasa yen tuturang (8a)

Jadmane ketiben gering (8i)

Pajahin olih corona (8a)

Ngawe larane runtuh (7u)

Cerik kelih tua bajang (8a)

Maka sami (4i)

Keni dukan ibu pertiwi (9i)

Artinya:

Sedih rasanya bila dikatakan
Umat manusia diserang penyakit Yang dinamakan virus corona Membuat timbulnya penderitaan Anak-anak, orang tua dan remaja Semuanya

Terkena duka derita dunia ini

Pada baris ke-4 (Ngawe larane runtuh) dan baris ke-7 (Keni dukan ibu pertiwi) terdapat pelanggaran kaidah pada lingsa yang seharusnya adalah baris ke-4 $8 u$ dan baris ke-7 $8 a$.

\section{Data 4}

Kudiang jani mangitungang (8a)

Pangendan jagate kali (8i)

Kaliput olih corona (8a)

Ngardi sami uyang bingung (8u)

Mogi gelis side brasta (8a)

Antuk eling (4i)

Nunas ice sarahina (8a)

Artinya:

Bagaimana caranya menyikapi

Keadaan dunia sekarang

Dicemari oleh virus corona

Membuat semua menjadi bingung

Semoga segeralah ia lenyap

Ingat selalu

Mohon keselamatan setiap hari

Pupuh Ginada di atas sudah sesuai dengan aturan pada lingsa tiap baris, yakni $8 a-8 i-8 a-8 u-8 a-4 i-8 a$.

\section{Data 5}

Uduh cening pianak bapa (8a)

Duhu saja bapa melid (8i)

Virus corona kinucap (8a)

Nawi lara tan paunduk (8u) 
Yen bengkung cening ngabanin

(8i)

Ngiring tinut (4u)

Atur uning pemerintah (8a)

Artinya:

Anaku yang ayah sayangi

Dulu mungkin benar ayah mampu

Tetapi semenjak virus corona melanda

Membuat penderitaan yang tak

karuan

Jangan membangkang pada aturan

Mari patuhi

Semua aturan pemerintah

Pupuh Ginada di atas belum sudah sesuai dengan aturan pada lingsa tiap baris, yakni $8 a-8 i-8 a-8 u-8 a-$ $4 i-8 a$. Pelanggaran terjadi pada baris ke-5 (Yen bengkung cening ngabanin) seharusnya $8 a$ dan baris ke-6 (Ngiring tinut) seharusnya $4 i$.

\section{Pupuh Ginanti}

\section{Data 6}

Coronane ngae inguh (8u)

Pipis telah buka jani (8i)

Kariawane dirumahkan (8a)

Kenkenang man makan jani (8i)

Tulungin je dewek titiang ( $8 a)$

Apang titiang tusing mati (8i)

Artinya

Virus corona membuat resah

Sekarang uang pun sudah habis

Banyak kariawan yang

dirumahkan

Bagaimana caranya untuk

memnuhi kebutuhn makan

Mohon bantulah diri saya
Agar saya tidak meninggal

kelaparan

Pupuh Ginanti di atas sudah sesuai dengan aturan terdiri atas 6 baris dengan pada lingsa $8 u-8 i$ -

$8 a-8 i-8 a-8 i$.

\section{Data 7}

Gumi jani uyak grubug (8u)

Virus corona kadanin (8i)

Ngawinang jatmane lara (8a)

Nora dados keparanin (8i)

Kudang dukun miwah balyan (8a)

Arang sida menambanin (8i)

Tekan sakit nora pangguh (8u)

Ten ngitungan sian lati (8i)

Sengkepisan menangkisang (8a)

Sakite negakin angin (8i)

Ngiring jenepna ring umah (8a)

Pada yatna sareng sami (8i)

Artinya:

Sekarang dunia sedang dilanda

wabah

Virus corona namanya

Membuat umat manusia menderita

Tidak dapat diobati

Sudah banyak para normal

Tak mampu menghentikannya

Tidak tau dari mana datangnya

Tak memandang siapapun

Sangat sulit mencegahnya

Datangnya seperti mengendari

angin

Mari sama-sama berdiam di

rumah

demi keselamatan bersama 
Kedua bait pada Pupuh Ginanti data 7 di atas sudah sesuai dengan aturan terdiri atas 6 baris dengan pada lingsa $8 u-8 i-8 a-8 i-8 a-8 i$.

\section{Data 8}

Sane mangkin tityang matur (8u)

Elingang piteket niki (8i)

Mangdene nenten keni corona

(10a)

Anggen maskere sesai (8i)

Ede pengkung, ngoyong jumah

(8a)

Taler tangane bersihin (8i)

Artinya:

Sekarang akan saya sampaikan Ingatlah penyampaian ini Agar tidak terkena virus corona Gunakanlah masker setiap hari Berdisiplinlah diam di rumah Ingat juga tangan harus dibersihkan

Pupuh Ginanti data 8 di atas belum sesuai dengan aturan pada lingsa $8 u-8 i-8 a-8 i-8 a-8 i$. Pelanggaran pada lingsa terjadi pada baris ke-3 yang seharusnya adalah $8 a$, tetapi dalam pupuh di atas dibuat $10 a$.

\section{Pupuh Sinom}

\section{Data 9}

Rikala gering corona (8a) Jagate sekadi mangkin (8i) Akehan usan mekarya (8a) Yan madolan sepi jampi (8i) Ngiring mangkin sareng sami (8i) Yan medue patut ngwantu (8u) Gotong royong laksanayang (8a) Medana punia akidik (8i)
Saling wantu (4u)

Welas asihe kawekas (8a)

Artinya:

Di saat virus corona

Seperti dunia saat in Apabila berjualan pembelinya sangat sepi Sekarang mari kita semua Berpikir melakukan yang benar Melaksanakan gotong-royong Berbagi rejeki Saling membantu Saling mengasihi selalu

Pupuh Sinom terdiri atas 10 baris dengan pada lingsa sebagai berikut: $\quad 8 a-8 i-8 a-8 i-7 i-8 u-8 a-8 i-$ 4u-8i. Pada pupuh Sinom data 9 di atas terjadi pelanggaran pada lingsa pada baris ke-5 seharusnya $7 i$, tetapi pada pupuh di atas dibuat $8 i$.

Beberapa tembang khas Bali (pupuh) tersebut jelas mengandung maksud ajakan kepada masyarakat untuk tetap mematuhi protokol kesehatan sesuai dengan imbauan pemerintah, seperti mencuci tangan, jaga jarak, dan tetap berada di rumah untuk menjalankan physical distancing dan social distancing. Unsur-unsur persuasif dengan bahasa yang kreatif yang digunakan dalam setiap pupuh tersebut mengandung maksud untuk 
mengajak masyarakat agar secara bersama-sama taat terhadap protokol kesehatan dan imbauan pemerintah. Pesan yang disampaikan dalam pupuh-pupuh tersebut secara tidak langsung mengedukasi masyarakat terkait dengan upaya penanggulangan Covid-19. Hal itu membuktikan bahwa bahasa dapat dikemas secara kreatif untuk menyampaikan pesan ataupun gagasan kepada masyarakat luas. Inilah yang menunjukkan kreativitas seseorang dalam menggunakan bahasa untuk berkomunikasi (Juliantari, 2020).

Adanya Covid-19 tersebut telah memaksa masyarakat untuk berpartisipasi dalam budaya media yang semakin bersifat digital dalam rangka mengedukasi masyarakat lainnya terkait dengan Covid19 ini. Di samping itu, adanya Covid-19 ini juga memaksa masyarakat untuk beradaptasi dengan kebiasaan baru menganai pola hidup bersih sebagaimana yang dikemukakan oleh Hidayat (2020), sehingga literasi terkait dengan berbagai hal tersebut memang sangat diperlukan oleh masyarakat sebagai bahan edukasi.

Dari uraian di atas tampak penggunaan bahasa sebagai media komunikasi secara kreatif yang dikemas ke dalam bentuk pupuh (tembang khas Bali), sehingga sosialisasi terhadap upaya penanggulangan Covid-19 dapat dilakukan melalui menembangkan pupuh tersebut.

\section{PENUTUP}

Berdasarkan uraian pembahasan tersebut dapat disimpulkan bahwa literasi masyarakat terkait dengan Covid-19 masih mengalami bias kognitif sehingga kesadaran masyarakat terhadap upaya pencegahannya pun menjadi belum terlalu optimal. Hal itu dibuktikan dengan berbagai perilaku masyarakat yang belum sepenuhnya mematuhi imbauan pemerintah terkait dengan berbagai kebijakan yang dikeluarkan. Oleh karena itu, salah satu strategi komunikasi kreatif yang dilakukan sebagai upaya untuk menyadarkan masyarakat dan membangun literasi masyarakat terkait dengan penanggulangan penyebaran Covid-19 adalah sosialisasi dengan menggunakan tembang khas Bali (pupuh). Ada 3 (tiga) pupuh yang dominan digunakan, yakni pupuh Ginada, pupuh Ginanti, dan pupuh Sinom. Ketiga pupuh ini dominan digunakan karena ketiga pupuh ini familier di tengah-tengah masyarakat Bali sebagai 
sasaran dalam kegiatan sosialisasi upaya penanggulangan Covid-19.

Kajian ini terbatas pada fenomena atau kasuistik yang terjadi di Karangasem Bali, sehingga masih sangat memungkinkan penulis lainnya untuk melakukan kajian serupa pada lokasi yang berbeda sehingga dapat dipetakan hal-hal yang berkaitan dengan pandemi Covid-19 dari berbagai wilayah di Indonesia.

\section{DAFTAR PUSTAKA}

Anitah, Sri. Media Pembelajaran. 2008. Surakarta :Panitia Sertifikasi Guru.

Buana, Dana Riksa. Analisis Perilaku Masyarakat Indonesia dalam Menghadapi Pandemi Virus Corona (Covid-19) dan Kiat Menjaga Kesejahteraan Jiwa. Salam, Jurnal Sosial dan Budaya Syar i. 2020. DOI: $10.15408 /$ sjsbs.v7i3.15082.

Hidayat. Langkah-langkah Strategis untuk Mencegah Covid-19 di Lembaga Permasyarakatan Indonesia. Jurnal Pendidikan Kesehatan. 2020; 9(1);43-55.

Juliantari, N. K. (2019). Strategi Penyelamatan Muka melalui Kesantunan Berbahasa dalam Komunikasi Umat Hindu di Karangasem. Ganaya : Jurnal Ilmu Sosial Dan Humaniora, 2(1), 1-17. Retrieved from https://jayapanguspress.penerbit.org /index.php/ganaya/article/view/180

Juliantari, N. K. (2020). Verbal and Nonverbal Communication Creativity In The New Normal
Era. Jayapangus Press Books, 263274. Retrieved from https://jayapanguspress.penerbit.org /index.php/JPB/article/view/477

Keputusan Gubernur Nomor 236/03B/HK/2020 tertanggal 10 Maret 2020 tentang Penanggulangan Covid-19.

Khoirul, A. Beredar rekaman mengerikan mayat-mayat tergeletak di jalanan Wuhan akibat virus corona ternyata beginilah fakta sebenarnya. 2020. Retrieved January 29, 2020, from https://intisari.grid.id/read/0320038 77/beredar-rekaman-mengerikanmayat-mayattergeletak-di-jalananwuhan-akibat-virus-coronyaternyata-beginilahfaktasebenarnya?page $=$ all

Kominfo. Laporan Isu Hoaks. 2020. Jakarta. Retrieved from https://www.kominfo.go.id/content/ all/laporan_isu_hoaks

Kompas. Tidak bisa musiman mengatasi hoaks politik. 2020. Retrieved from https://kompas.id/baca/utama/2020/ 01/20/tidak-bisa-musimanmengatasi-hoakspolitik/

Mulyadi dan Risminawati. Model-model Pembelajaran Inovatif di Sekolah Dasar. 2009. Surakarta: FKIP UMS.

Pradana, Casman, Nur'aini. Pengaruh Kebijakan Social Distancing pada Wabah Covid-19 terhadap Kelompok rentan di Indonesia. Jurnal Kebijakan Kesehatan Indonesia: JKKI. 2020; 9(2). https://doi.org/10.22146/jkki.55575. Sanjaya, Wina. Strategi Pembelajaran Berorientasi Standar Proses. 2009. Pendidikan. Prenada : Jakarta. 
SK Nomor 273/04-G/HK/2020 tentang Pembentukan dan Susunan Keanggotaan GTPP di Provinsi Bali.

SK Nomor 274/01-C/H/2020 tentang pembentukan dan susunan keanggotaan penanganan dampak dan pemulihan akibat Covid-19 di Provinsi Bali.

Surat Edaran Bersama Nomor: 019/PHDIBali/III/2020; Nomor: 019/MDA-
Prov Bali/III/2020; Nomor: 510/Kesra/B.Pem.Kesra, tanggal 17 Maret 2020 tentang Pelaksanaan Rangkaian Hari Suci Nyepi Tahun Saka 1942 di Bali.

Widiatmojo. Literasi Visual sebagai Penangkal Foto Hoax Covid-19. 2020; 6(1): 114-127. 